\title{
Impact of Fertility Levels and Biofertilizers on Root Architecture, Yield and Nutrient Uptake of Chickpea (Cicer arietinum L.) Crop
}

\author{
Gaurav Verma ${ }^{1}$, D. D. Yadav ${ }^{2}$, Amit Kumar*, R. Singh ${ }^{3}$, Subhash Babu ${ }^{4}$, \\ R. K. Avasthe ${ }^{3}$, B. A. Gudade ${ }^{5}$ and V. K. Sharma ${ }^{4}$ \\ ${ }^{1}$ CCSHAU, Hisar, India \\ ${ }^{2}$ CSAUAT, Kanpur, India \\ ${ }^{3}$ ICAR-NOFRI, Tadong, Gangtok, Sikkim, India \\ ${ }^{4}$ ICAR-IARI, New Delhi, India \\ ${ }^{5}$ ICRI, RRS, Spices Board, Tadong, Gangtok, Sikkim, India \\ *Corresponding author
}

Keywords

Biofertilizers, Chickpea, Root architectures, Soil fertility, Yield

Article Info

Accepted:

15 January 2020

Available Online:

10 February 2020
A field experiment was conducted during rabi season of 2016-2017 at the Students' Instructional Farm of Chandra Shekhar Azad University of Agriculture and Technology, Kanpur, Uttar Pradesh to assess the "impact of fertility levels and biofertilizers on root architecture, yield and nutrient uptake by crop". The experiment was comprised of 12 treatment combination in split plot design with three replications. The results showed that, application of $100 \%$ RDF significantly enhanced root parameters, yield and nutrient uptake over control plot. Among the different biofertilizers treatments, application of Rhizobium + PSB + PGPR had significant effect on root parameters and enhanced yield and nutrient uptake as compared to Rhizobium + PGPR. The combined application of $100 \%$ RDF with Rhizobium + PSB + PGPR resulted significantly higher yield of chickpea during rabi season.

\section{Introduction}

Chickpea is the world's third most important winter food legume crop. In our country, it covered 9.18 mha area, with $8.22 \mathrm{mt}$ production and $900 \mathrm{~kg} / \mathrm{ha}$ productivity (Anonymous, 2017). Among the leguminous crops, it has important position due to its nutritious value (17-23\% protein) which is deficient in the diet of majority of peoples. It is not only supply the protein but also enhances the soil fertility and maintain the soil health. Bio-fertilizers contains living micro-organisms, when it is applied to seeds, 
plant surfaces, or soil, colonizes the rhizosphere and promotes growth by increasing the supply or availability of nutrients to host plant (Dinesh et al., 2014). It augments the biochemical processes in soil i.e., nitrogen fixation, phosphorus solubilization and mobilization, zinc solubilization, decomposition of organic wastes, nutrient cycling, production of plant growth promoting substances and pathogen control. Biofertilizers provide an economically, attractive and ecologically sound means of fertilization and are important for making agriculture more sustainable in the era of climate change (Giagnoni et al., 2016). To meet the rising demand, a quantum jump in chickpea production is required. But, majority of farmers usually grow pulses in marginal land with indiscriminate use of chemical fertilizers without biofertilizers and other faulty management practices that resulted in reduction of organic matter content and creates multi-nutrient deficiency in soil (Das et al., 2016). Productivity of chick pea is less compared to national average productivity. Therefore, there is a need of present hour to find out eco-friendly, feasible and cheaper options to meet the nutrient need of crop grown in different cropping systems for maintaining soil fertility and crop productivity.

\section{Materials and Methods}

Field experiment was conducted during rabi season of 2016-2017 at the Students' Instructional Farm of Chandra Shekhar Azad University of Agriculture and Technology, Kanpur, Uttar Pradesh is situated at $25^{\circ} 18^{\prime} \mathrm{N}$ latitude, $83^{\circ} 03^{\prime} \mathrm{E}$ longitude and altitude of about $80.71 \mathrm{~m}$ above mean sea level. The soil of experimental field was sandy clay loam in texture, bulk density $\left(1.52 \mathrm{Mg} / \mathrm{m}^{3}\right), \mathrm{pH} 7.6$, EC $(0.11 \mathrm{dS} / \mathrm{m})$, low is organic carbon $(0.30 \%)$ and available $\mathrm{N}(188 \mathrm{~kg} / \mathrm{ha})$, medium in available $\mathrm{P}(13.4 \mathrm{~kg} / \mathrm{ha})$ and available $\mathrm{K}$
(173.3 kg/ha). The experiment was comprised of 12 treatment combinations, which comprised of 4 treatments $\left[\mathrm{F}_{1}\right.$ (control), $\mathrm{F}_{2}$ (RDF $\left.100 \%), \mathrm{F}_{3}(75 \% \mathrm{RDF}), \mathrm{F}_{4}(50 \% \mathrm{RDF})\right]$ in main plot and 3 treatments $\left[\mathrm{B}_{1}\right.$ (Rhizobium + PSB), $\quad \mathrm{B}_{2}$ (Rhizobium + PGPR), $\mathrm{B}_{3}$ (Rhizobium + PSB + PGPR)] in sub plots, laid out in split plot design with three replications. The fertilizer nutrients were supplied through urea, diammonium phosphate (DAP) and muriate of potash (MOP). Starter dose of nitrogen and full dose of phosphorus and potassium as per treatment were applied as basal. Before sowing, seeds were treated with biofertilizers $(20 \mathrm{~g} / \mathrm{kg}$ of seeds) as per standard procedure after drying of six hours under shade. Chickpea cultivar Udai (KPG 59) was sown at $40 \times 10 \mathrm{~cm}$ crop geometry with a seed rate of $75 \mathrm{~kg} / \mathrm{ha}$ apart during the first week of December. Fallow the standerd procedures and observations were recorded on root parameters, yield and nutrient uptake.

Nutrient concentration and uptake by crop was calculated by using the following expression:

Nutrient uptake $\left(\mathrm{kg} \mathrm{ha}^{-\mathbf{1}}\right)$ in grain/stover $=[\%$ nutrient concentration in grain/stover $\times$ grain/stover yield $\left.\left(\mathrm{kg} \mathrm{ha}^{-1}\right)\right]$.

Total nutrient uptake $\left(\mathrm{kg} \mathrm{ha}{ }^{-\mathbf{1}}\right)=$ Nutrient uptake by grain + Nutrient uptake by stover.

The data collected of different parameters were subjected to appropriate statistical analysis under Split Plot Design by following the procedure of ANOVA analysis of variance (SAS Software packages, SAS EG 4.3). Significance of difference between means was tested through ' $F$ ' test and the least significant difference (LSD) was worked out where variance ratio was found significant for treatment effect. The treatment effects were tested at $5 \%$ probability level for their significance. 


\section{Results and Discussion}

Root architectures (Root dry weight, number of nodules per plant, nodules dry weight)

Results showed that the different fertility levels and biofertilizers had significant effect on root parameters, yield and nutrient uptake but did not influenced nutrient concentration. However, significantly maximum root dry weight and nodule dry weight was registered by application of Rhizobium + PGPR than compared to Rhizobium + PSB and Rhizobium + PSB + PGPR. Whenever, highest number of nodules were recorded with the application of Rhizobium + PGPR which was statistically at par with Rhizobium + PSB + PGPR but significantly higher than Rhizobium + PSB and Rhizobium + PSB. This might be due to nutrient levels had favourable effect on plant growth over control treatment that results better nutrient availability and increased number of metabolic processes taking place in the plant body, which results more root dry weight, number of nodules and nodule dry weight (Egamberdieva et al., 2015).

Higher root dry weight was noticed under Rhizobium + PSB + PGPR which was statically at par with Rhizobium + PSB but significantly higher than Rhizobium+ PGPR. However, maximum number of nodules and nodule dry weight was recorded under Rhizobium + PSB + PGPR which was significantly higher than Rhizobium + PSB and Rhizobium + PGPR. The probable reasons for such results could be the growth promoting substances secreted by the microbial inoculants, which in turn might have led to better root development, better transpiration of water and enhanced uptake of nutrients that results more root dry weight, number of nodules and nodule dry weight (Singh et al., 2015).

\section{Yield (t/ha)}

Seed and stover yield of chickpea was significantly influenced due to different fertility levels and biofertilizers. However, application of $100 \%$ RDF along with Rhizobium + PSB + PGPR resulted higher seed yield (20 q/ha) which was statistically at par with $75 \%$ RDF along with application Rhizobium + PSB + PGPR but significantly higher than other fertility levels.

Higher stover yield was registered with $100 \%$ RDF which was statistically at par with $75 \%$ RDF and significantly higher than other treatments. The increase in seed and stover yield due to adequate nutrients supply which helps in better translocation of photosynthates from source to sink that results more growth and yield attributes which ultimately more yield (Singh et al., 2016).

Application of Rhizobium + PSB + PGPR was noticed significantly higher seed and stover yield compared to other treatments respectively. It might be due to proper establishment of Rhizobium strain which supply nitrogen and secreted certain growth promoting substances that results better root development and enhances the uptake and deposition of nutrients (Gupta et al., 2018).

\section{Nutrient concentration \%}

None of the fertility levels and biofertilizers showed significant difference in nutrient content i.e. nitrogen, phosphorus potassium and sulphur in the seed and stover because decrease of nutrient concentration with advancement of crop age under all the fertility levels and biofertilers was observed. This might be due to increased dry matter in later stage and thus affecting dilution in nutrient (N, P, K and S) concentration (Tomasi et al., 2008). 
Table.1 Effect of different fertility levels and biofertilizers on root parameters and nutrient concentration of chickpea crop

\begin{tabular}{|c|c|c|c|c|c|c|c|c|c|c|c|}
\hline \multirow[t]{2}{*}{ Treatment } & \multirow{2}{*}{$\begin{array}{c}\begin{array}{c}\text { Root dry } \\
\text { weight } \\
\text { (gram/plant) }\end{array} \\
\text { At harvest }\end{array}$} & \multirow{2}{*}{$\begin{array}{c}\begin{array}{c}\text { Number of } \\
\text { nodules/plant }\end{array} \\
60 \text { DAS }\end{array}$} & \multirow{2}{*}{$\begin{array}{c}\begin{array}{c}\text { Nodule } \\
\text { dry } \\
\text { weight } \\
\text { (mg/plant) }\end{array} \\
60 \text { DAS }\end{array}$} & \multicolumn{2}{|c|}{$\begin{array}{c}\mathbf{N} \\
\text { concentration } \\
\%\end{array}$} & \multicolumn{2}{|c|}{$\begin{array}{c}\text { P concentration } \\
\%\end{array}$} & \multicolumn{2}{|c|}{$\begin{array}{c}\mathrm{K} \\
\text { concentration } \\
\%\end{array}$} & \multicolumn{2}{|c|}{$\begin{array}{c}\text { S concentration } \\
\%\end{array}$} \\
\hline & & & & Seed & Stover & Seed & Stover & Seed & Stover & Seed & Stover \\
\hline \multicolumn{12}{|c|}{ Fertility levels } \\
\hline F1 & 0.48 & 15.8 & 52.4 & 3.27 & 0.81 & 0.31 & 0.26 & 0.46 & 0.36 & 0.23 & 0.26 \\
\hline F2 & 0.71 & 19.0 & 62.4 & 2.81 & 0.98 & 0.48 & 0.43 & 0.63 & 0.51 & 0.34 & 0.39 \\
\hline F3 & 0.64 & 17.9 & 56.5 & 2.95 & 0.88 & 0.38 & 0.33 & 0.53 & 0.42 & 0.29 & 0.34 \\
\hline F4 & 0.52 & 18.1 & 54.8 & 3.10 & 0.83 & 0.33 & 0.28 & 0.48 & 0.37 & 0.25 & 0.28 \\
\hline $\mathrm{SEm} \pm$ & 0.02 & 0.48 & 1.48 & 0.14 & 0.04 & 0.04 & 0.03 & 0.04 & 0.03 & 0.03 & 0.03 \\
\hline $\begin{array}{l}\text { CD } \\
(P=0.05)\end{array}$ & 0.06 & 1.67 & 5.14 & NS & NS & NS & NS & NS & NS & NS & NS \\
\hline \multicolumn{12}{|c|}{ Bio fertilizers } \\
\hline B1 & 0.59 & 17.6 & 56.7 & 3.03 & 0.89 & 0.39 & 0.34 & 0.54 & 0.43 & 0.28 & 0.32 \\
\hline B2 & 0.55 & 15.7 & 51.5 & 2.99 & 0.83 & 0.33 & 0.28 & 0.48 & 0.37 & 0.25 & 0.29 \\
\hline B3 & 0.62 & 19.8 & 61.3 & 3.08 & 0.90 & 0.40 & 0.35 & 0.55 & 0.45 & 0.30 & 0.35 \\
\hline SEm \pm & 0.01 & 0.37 & 1.01 & 0.09 & 0.03 & 0.02 & 0.03 & 0.03 & 0.03 & 0.02 & 0.02 \\
\hline $\begin{array}{l}\text { CD } \\
(P=0.05)\end{array}$ & 0.04 & 1.12 & 3.04 & NS & NS & NS & NS & NS & NS & NS & NS \\
\hline
\end{tabular}

Where, F1- Control, F2- RDF 100\%, F3- RDF 75\%, F4- RDF 50\%, B1- Rhizobium + PSB, B2- Rhizobium+ PGPR, B3- Rhizobium + PSB + PGPR 
Table.2 Effect of fertility levels and bio fertilizers on nutrient uptake of chickpea

\begin{tabular}{|c|c|c|c|c|c|c|c|c|c|c|c|c|c|c|}
\hline \multirow[t]{2}{*}{ Treatments } & \multirow{2}{*}{$\begin{array}{c}\text { Seed } \\
\text { yield } \\
\text { (q/ha) }\end{array}$} & \multirow{2}{*}{$\begin{array}{c}\text { Stover } \\
\text { yield } \\
\text { (q/ha) }\end{array}$} & \multicolumn{3}{|c|}{ N uptake (kg/ha) } & \multicolumn{3}{|c|}{ P uptake (kg/ha) } & \multicolumn{3}{|c|}{ K uptake (kg/ha) } & \multicolumn{3}{|c|}{ S uptake (kg/ha) } \\
\hline & & & Seed & Stover & Total & Seed & Stover & Total & Seed & Stover & Total & Seed & Stover & Total \\
\hline \multicolumn{15}{|c|}{ Fertility levels } \\
\hline F1 & 12.1 & 23.3 & 39.7 & 18.8 & 58.6 & 3.64 & 6.09 & 10.0 & 5.68 & 8.26 & 13.8 & 2.83 & 6.16 & 8.99 \\
\hline F2 & 18.0 & 31.9 & 50.6 & 31.4 & 82.0 & 8.56 & 13.84 & 22.5 & 11.50 & 16.50 & 27.9 & 6.27 & 12.41 & 18.5 \\
\hline F3 & 16.3 & 29.8 & 48.4 & 26.3 & 74.5 & 6.26 & 9.92 & 16.2 & 8.69 & 12.80 & 21.5 & 4.84 & 10.28 & 15.1 \\
\hline F4 & 15.6 & 29.5 & 48.5 & 24.6 & 73.0 & 5.25 & 8.36 & 13.5 & 7.55 & 11.11 & 18.5 & 3.97 & 8.28 & 12.2 \\
\hline SEm \pm & 0.34 & 0.9 & 1.36 & 0.74 & 2.17 & 0.22 & 0.29 & 0.48 & 0.21 & 0.29 & 0.66 & 0.14 & 0.32 & 0.45 \\
\hline $\begin{array}{l}\text { CD } \\
(P=0.05)\end{array}$ & 1.11 & 2.78 & 4.69 & 2.55 & 7.52 & 0.75 & 1.01 & 1.67 & 0.71 & 1.01 & 2.30 & 0.49 & 1.10 & 1.54 \\
\hline \multicolumn{15}{|c|}{ Bio fertilizers } \\
\hline B1 & 15.7 & 29.1 & 47.5 & 26.0 & 73.54 & 6.25 & 10.08 & 16.4 & 8.70 & 12.70 & 21.3 & 4.58 & 9.51 & 14.0 \\
\hline B2 & 13.1 & 24.6 & 39.0 & 20.6 & 59.5 & 4.36 & 7.11 & 11.4 & 6.40 & 9.15 & 15.5 & 3.38 & 7.11 & 10.3 \\
\hline B3 & 17.7 & 32.1 & 53.9 & 29.2 & 83.1 & 7.17 & 11.46 & 18.8 & 9.97 & 14.67 & 24.4 & 5.47 & 11.23 & 16.7 \\
\hline SEm \pm & 0.28 & 0.74 & 1.07 & 0.62 & 1.75 & 0.22 & 0.30 & 0.35 & 0.28 & 0.35 & 0.55 & 0.12 & 0.24 & 0.37 \\
\hline $\begin{array}{l}\text { CD } \\
(P=0.05)\end{array}$ & 0.85 & 2.01 & 3.20 & 1.86 & 5.26 & 0.66 & 0.91 & 1.04 & 0.84 & 1.06 & 1.65 & 0.36 & 0.72 & 1.11 \\
\hline
\end{tabular}

Where, F1- Control, F2- RDF 100\%, F3- RDF 75\%, F4- RDF 50\%, B1- Rhizobium + PSB, B2- Rhizobium+ PGPR, B3- Rhizobium + PSB + PGPR 


\section{Nutrient uptake (kg/ha)}

Different fertility levels and biofertilizers had significant effect on nutrient. The maximum nitrogen uptake by the seed was recorded with the application of $100 \%$ RDF which was statistically on par with $75 \% \mathrm{RDF}$ and $50 \%$ RDF but significantly higher than control treatment. Maximum nitrogen uptake by the stover was recorded with the application of $100 \%$ RDF which was significantly higher than other treatment. But maximum total nitrogen uptake by the crop was noticed with the application of $100 \%$ RDF which was statistically on par with $75 \%$ RDF but significantly higher than $50 \% \mathrm{RDF}$ and control treatment. This might be due to more total $\mathrm{N}$ uptake at higher fertility levels were revealed to better $\mathrm{N}$ nutrition and it accumulation in seed and stover (Singh et al., 2018). However, highest nutrients (total nitrogen, phosphorus, potassium and sulphur) uptake by the crop was recorded with the application of Rhizobium + PSB + PGPR which was significantly higher than other treatments. This may be due to the fact that microorganisms helps in nitrogen fixation, solubilization, mobilization of plant nutrients and reduce the need for chemical fertilizers and enhances the nutrients availability and uptake to plants Patel et al., 2013). Moreover, the increase in nitrogen concentration may be due to inoculation of PGPR strains which show nitrate reductase activities and facilitate the uptake of ammonia and amino acids produced by plants Das et al., (2016). However, maximum total phosphorus, potassium and sulphur uptake by the crop was recorded with the application of $100 \% \mathrm{RDF}$ which was significantly higher than other treatments. The more total nutrients uptake at higher fertility levels revealed better nutrition and its accumulation in seed and stover Singh and Prasad (2008). However, maximum total phosphorus, potassium and sulphur uptake by the crop was recorded with the application of
Rhizobium + PSB + PGPR which was significantly higher than other treatments. This may be due to biofertilizers were released several organic acids which improves the physicochemical and biological properties of soil and increasing availability of macro and micro- nutrients to crop for better growth and development (Jaipaul et al., 2011). It have the diversity of microorganisms like Actinomycetes, Azotobacter, Rhizobium, Nitrobacter and phosphate solubilising bacteria (PSB) and supplying the available nutrients, valuable growth promoting substances, and enzymes which resulting in increased content and uptake of nutrients by crop (Khaitov et al., 2016).

Based on the finding of the present study, it can be inferred that application of 100\% RDF along with Rhizobium + PSB + PGPR was found better in achieving the root architecture, yield and nutrient uptake by crop during rabi season in central zone of Uttar Pradesh.

\section{References}

Anonymous. 2017. Agricultural Statistics at a Glance 2016. Directorate of Economics \& Statistics, Department of Agriculture, Cooperation and Farmers Welfare, Ministry of Agriculture \& Farmers Welfare, Govt. of India, New Delhi, p.479.

Das, A., Babu, S., Yadav, G.S., Ansari, M.A., Singh, R., Baishya, L.K., Rajkhowa, D.J. and Ngachan, S.V. 2016. Status and strategies for pulses production for food and nutritional security in north-eastern region of India. Indian Journal of Agronomy 61: (Special issue): 43-57.

Dinesh Kumar, Arvadiya, L.K., Kumawat, A.K., Desai, K.L. and Patel, T.U. 2014. Yield, protein content, nutrient content and their uptake in chickpea (Cicer arietinum L.) as influenced by graded levels of fertilizers and bio-fertilizers. Trends in Biosciences 7(24): 4229-4233.

Egamberdieva, D., Abdiev, A. and Khaitov, B. 
2015. Synergistic interactions among root- associated bacteria, rhizobia and chickpea under stress conditions. In: Plant Environment Interaction: Responses and Approaches to Mitigate Stress, M.M. Azooz, P. Ahmad (Eds.), John Wiley \& Sons, Ltd., pp. 250-261.

Giagnoni, L., Pastorelli, R., Mocali, S., Arenella, M., Nannipieri, P. and Renella, G. 2016. Availability of different nitrogen forms changes the microbial communities and enzyme activities in the rhizosphere of maize lines with different nitrogen use efficiency. Applied Soil Ecology 98: 3038 .

Gupta, G., Dhar, S., Dass, A., Sharma, V.K., Singh, R.K., Kumar, A., Jinger, D. and Kumar, A. 2018. Influence of bioinoculant mediated organic nutrient management on productivity and profitability of pigeonpea (Cajanus cajan) in a semi-arid agro-ecology. Indian Journal of Agricultural Sciences 88(10): 1093-6.

Jaipaul, Sharma, S., Dixit, A.K. and Sharma, A.K. 2011. Growth and yield of capsicum and garden pea as influenced by organic manures and biofertilizers. Indian Journal of Agricultural Sciences 81(7): 637-42.

Khaitov, B., Kurbonov, A., Abdiev, A. and Adilov, M. 2016. Effect of chickpea in association with Rhizobium to productivity and soil fertility. Eurasian Journal of Soil Science 5(2): 105-112.

Patel, P.S., Ram, R.B., Jayprakash. and Meena, M.L. 2013. Effect of biofertilizers on growth and yield attributes of pea (Pisum sativum L.) Trends in Biosciences 6(2):
174-76.

Singh, R. and Prasad, K. 2008. Effect of vermicompost, Rhizobium and DAP on growth, yield and nutrient uptake by chickpea. Journal of Food legumes 21(2): 112-114.

Singh, R.K., Dhar, S., Dass, A., Sharma, V.K., Kumar, A., Gupta, G. and Kumar, B. 2018. Productivity and profitability of soybean (Glycine max) and wheat (Triticum aestivum) genotypes grown in sequence under system of crop intensification. Indian Journal of Agricultural Sciences 88(9): 1407-12.

Singh, R., Babu, S., Avasthe, R.K., Yadav, G.S. and Rajkhowa, D.J. 2015. Influence of tillage and organic nutrient management practices on productivity, profitability and energetic of vegetable pea (Pisum sativum L.) in rice - vegetable pea sequence under hilly ecosystems of North East India. Research on Crops 16(4): 683-688.

Singh, R., Babu, S., Avasthe, R.K., Yadav, G.S. and Rajkhowa, D.J. 2016. Productivity, economic profitability and energy dynamics of rice (Oryza sativa L.) under diverse tillage and nutrient management practices in rice-vegetable pea cropping system of Sikkim Himalayas. Indian Journal of Agricultural Sciences 86(3): 326-30.

Tomasi, N., Weisskopf, L., Renella, G., Landi, L., Pinton, R., Varanini, Z., Nannipieri, P., Torrent, J., Martinoia, E. and Cesco, S. 2008. Flavonoids of white lupin roots participate in phosphorus mobilization from soil. Soil Biology and Biochemistry 40: 1971-74.

\section{How to cite this article:}

Gaurav Verma, D. D. Yadav, Amit Kumar, R. Singh, Subhash Babu, R. K. Avasthe, B. A. Gudade and Sharma, V. K. 2020. Impact of Fertility Levels and Biofertilizers on Root Architecture, Yield and Nutrient Uptake of Chickpea (Cicer arietinum L.) Crop. Int.J.Curr.Microbiol.App.Sci. 9(02): 2018-2024. doi: https://doi.org/10.20546/ijcmas.2020.902.230 